ISSN 0103-8478

\title{
Physicochemical properties of three sugary cassava landraces
}

\author{
Propriedades físico-químicas de três acessos de mandiocaba
}

\author{
Hugo Antonio Lima de Souza ${ }^{I}$ Ádria de Sousa Bentes ${ }^{I}$ Taiana Marina Souza LadeiraII \\ Alessandra Santos Lopes ${ }^{\mathrm{II}}$ Rosinelson da Silva Pena ${ }^{\mathrm{II}^{*}}$
}

\section{ABSTRACT}

This study evaluates the physical and physicochemical properties of three sugary cassava (Manihot esculenta Crantz) landraces: São Francisco Bag 3, Manicueira 62, and Castanhal Iracema. These three landraces showed high estimated productivity $\left(\geq 3.93 \mathrm{~kg}\right.$ plant $\left.^{-1}\right)$ and had a high sugar

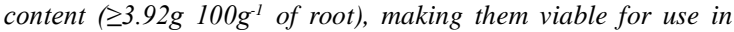
syrup production, especially the São Francisco Bag 3 landrace $\left(4.76 \mathrm{~g}_{100 \mathrm{~g}^{-1}}\right)$. The Manicueira 62 landrace had the highest starch content $\left(4.40 \mathrm{~g}^{100 \mathrm{~g}^{-1}}\right)$. The three sugary cassava landraces exhibited high levels of cyanide $\left(>195 \mathrm{mg} \mathrm{kg}^{-1}\right)$, indicating the need for processing prior to consumption.

Key words: Manihot esculenta Crantz, sugar, starch, composition.

\section{RESUMO}

Neste trabalho, foram avaliadas propriedades físicas e físico-químicas das raízes de três acessos de mandiocaba (Manihot esculenta Crantz): São Francisco Bag 3, Manicueira 62 e Castanhal Iracema. Os três acessos apresentaram elevada produtividade estimada $\left(\geq 3,93 \mathrm{~kg}\right.$ planta $\left.^{-1}\right)$ e as suas raízes

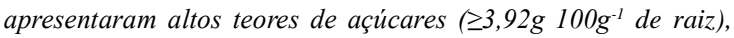
apresentando-se como uma alternativa para a produção de xarope, particularmente o acesso São Francisco Bag 3 (4,76g $\left.100 \mathrm{~g}^{-1}\right)$. O acesso Manicueira 62 foi o que apresentou o maior conteúdo de amido $\left(4,40 \mathrm{~g} 100 \mathrm{~g}^{-1}\right)$. As três raízes estudadas apresentaram altos níveis de cianeto total $\left(>195 \mathrm{mg} \mathrm{kg}^{-1}\right)$, o que indica que elas também necessitam ser processadas antes de serem consumidas.

Palavras-chave: Manihot esculenta Crantz, açúcar, amido, composição.

\section{INTRODUCTION}

Cassava (Manihot esculenta Crantz) is a very important crop for Brazil, the world's thirdlargest producer of this root (FAO, 2011). However, this crop receives little attention within the context of the national economy due to the low verticalization of the Brazilian supply chain (CEREDA \& VILPOUX, 2003). The Manihot genus (ALBUQUERQUE, 1969; HILLOCKS et al., 2002) may have originated and diversified in Brazil where there is great genetic variety, mainly of local diversity, that is restricted to a few agriculturists. These varieties are known as landraces (SIQUEIRA et al., 2010).

Part of this variety is preserved in banks of germplasm around the world (FUCCILLO et al., 1997). The biggest active germplasm bank in Brazil belongs to Embrapa, located in Cruz das Almas, Bahia (Brazil) which contains approximately 1,700 landraces (FUKUDA et al., 1997). There are several projects related to the genetic improvement of cassava which attempt to increase its productivity and make it more resistant to pests, but few are related to producing roots with compounds of greater added value (TAYLOR et al., 2004).

Within this context, a group of landraces indigenous to the Brazilian Amazon, widely-known as sugary cassava or "mandiocaba", stand out from

'Departamento de Ciência de Alimentos, Faculdade de Engenharia de Alimentos, Universidade de Campinas (UNICAMP), Campinas, SP, Brasil.

IFaculdade de Engenharia de Alimentos, Instituto de Tecnologia (ITEC), Universidade Federal do Pará (UFPA), Rua Augusto Corrêa, 01, Guamá, 66075-900, Belém, PA, Brasil. E-mail: rspena@ufpa.br. *Autor para correspondência. 
the other varieties of cassava in terms of their high sugar and low starch content, used by the indigenous people of the Amazonia to make a sweet porridge known as "manicueira" (CARVALHO et al., 2004). The production of a concentrate rich in glucose, by concentrating "manipueira" (liquid obtained by crushing and filtering of cassava), is one of the possible industrial uses of sugary cassava (CARDOSO et al., 2004).

The objective of this study was to quantify sugars and other compounds of three sugary cassava (Manihot esculenta Crantz) landraces produced in the state of Pará, Brazil.

\section{MATERIALS AND METHODS}

Materials

Three sugary cassava landraces provided by the Active Germplasm Bank of the Empresa Brasileira de Pesquisa Agropecuária (EMBRAPA/ CPATU) were used in the study: Manicueira 62, Castanhal-Iracema (nine-month-old plant) and São Francisco Bag 3 (twelve-month-old plant). The yields were obtained by weighing the roots of each landrace. The average root yield was evaluated on three plants of each landrace, with and without the peel.

Analyses

Proximate composition - The following analyses were performed in the sugary cassava roots: moisture content: the gravimetric method was used in an air-circulating oven at $105^{\circ} \mathrm{C}$ based on AOAC (1997) method 925.10; ashes: the sample was incinerated in Mufla oven at $550^{\circ} \mathrm{C}$ based on AOAC (1997) method 923.03; proteins: the Kjeldahl method was used with a 6.25 nitrogen-protein correlation factor based on AOAC (1997) method 920.87; lipids: extracted with mixing of solvents using the BLIGH \& DYER (1959) method; total and reducing sugars: Lane-Eynon titration method based on AOAC (1997) method 920.183b; starch: acid hydrolysis using the RICKARD \& BEHN (1987) method; insoluble and total dietary fibers: enzymatic/gravimetric method using the $\alpha$-amilase thermo-resistant (EC 3.2.1.1), protease (EC 3.4.21.26) and amyloglucosidase (EC 3.2.1.3) enzymes based on AOAC (1997) methods 985.29 and 991.42. The soluble fiber content was determined by the difference.

Glucose, fructose and sucrose contents Soluble sugars were extracted three times with $80 \%$ ethanol at $80^{\circ} \mathrm{C}$. The supernatants were combined, and the ethanol was evaporated under vacuum. The residues were reconstituted with water, filtered through $0.22 \mu \mathrm{m}$ membrane filters, and analyzed by
HPAE-PAD. The chromatographic analysis was performed on a Dionex DX 500 instrument equipped with a PAD system (ED 40). The analytical column employed was a Carbopac PA1 $(250 \times 4 \mathrm{~mm}, 5 \mu \mathrm{m}$ particle size). The flow rate was kept constant at

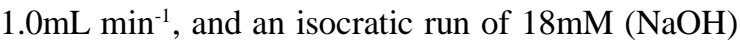
over 25min (DER AGOPIAN et al., 2008).

Physicochemical properties of the roots Soluble solids: direct reading via an Atago optical refractometer at $20^{\circ} \mathrm{C}$ based on AOAC (1997) method 932.12; $\mathrm{pH}$ : direct reading via a Marconi $\mathrm{pH}$ meter based on AOAC (1997) method 943.02; total titratable acidity: titration method based on AOAC (1997) method 942.15; water activity $\left(a_{w}\right)$ : direct reading via a Decagon Aqualab 3TE digital thermo hygrometer at $25^{\circ} \mathrm{C}$; free and total cyanide $(\mathrm{HCN})$ : enzymatic/spectrophotometric method based on ESSERS (1993); and color: tristimulus colorimetry using a model CR 400 MINOLTA colorimeter, with $\mathrm{L}^{*}, \mathrm{a}^{*}$ and $\mathrm{b}^{*}$ values based on the parameters D65 (day light) and $10^{\circ}$ (observer angle) according to CIE Lab standards (CHROMA METER, 1989).

\section{RESULTS AND DISCUSSION}

Root yields per plant

Table 1 shows the average root yield per landrace. The São Francisco Bag 3 landrace had the highest yield $(8.16 \mathrm{~kg}$ root with peel/plant and $7.32 \mathrm{~kg}$ root without peel/plant) and also had the highest root/ peel ratio (9.71). The Castanhal Iracema landrace had the lowest yield $(3.93 \mathrm{~kg}$ root with peel/plant and $3.46 \mathrm{~kg}$ root without peel/plant) and the Manicueira 62 landrace had the lowest root/peel ratio (7.64), however, this difference in yield may result from time of harvesting, since landrace with the highest yield was the one harvested with 12 months after planting date compared to the others harvested at 9 months. Thus, future studies to determine the real productivity of these landraces are needed. Considering just the recommended growing space (10,000plants ha $\left.{ }^{-1}\right)$ (HILLOCKS et al., 2002) and not taking into account pests and other losses, the productivity of the three landraces $\left(\geq 39.3\right.$ ton $\left.\mathrm{ha}^{-1}\right)$ would be more than double the current rate of Brazilian productivity, which is 14ton ha-1 (FAO, 2011). VIEIRA et al. (2008) determined the productivity of other four sugary cassava landraces and found them to be low (2.08.9ton ha' $\mathrm{ha}^{-1}$.

Root composition

Table 2 shows the data on the composition of sugary cassava landraces. The São Francisco Bag 
Table 1 - Root yields per plant by sugary cassava landraces.

\begin{tabular}{lccc}
\hline & & & \\
Yield & S. F. Bag 3 & Manicueira 62 & Castanhal Iracema \\
\hline Root with peel $^{\mathrm{b}}$ & 8.16 & 3.73 & 3.93 \\
Root without peel $^{\mathrm{b}}$ & 7.32 & 4.98 & 3.46 \\
Ratio root/peel & 9.71 & 7.64 & 8.36 \\
\hline
\end{tabular}

${ }^{\mathrm{a}}$ São Francisco Bag $3 ;{ }^{\mathrm{b}} \mathrm{kg}$ plant ${ }^{-1}$.

3 landrace had the highest water content of the three (though all three were above $90 \%$ ) while conventional cassava has a water content of approximately $65 \%$ (CEREDA, 2001; HILLOCKS et al., 2002).

The Manicueira 62 landrace had the highest levels of reducing and total sugars (4.67 and

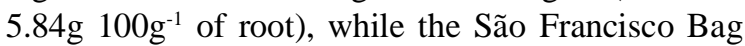
3 landrace had the greatest yields of those sugars per plant (290 and 350g plant ${ }^{-1}$ ). However, the three landraces had high levels of reducing sugars $(\geq 3.71 \mathrm{~g}$

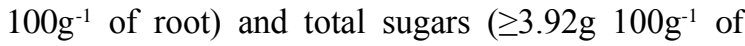
root) when compared to those found in conventional cassavas $\quad\left(\leq 0.48\right.$ and $\leq 0.83 \mathrm{~g} 100 \mathrm{~g}^{-1}$ of root, respectively) (HILLOCKS et al., 2002). The reducing sugars, consisting mainly of glucose, represent the largest part of the total sugars in the three sugary cassava landraces $(\geq 80 \%)$, however according to CARVALHO et al. (2004), on sugary cassava exist other sugars that were not quantified in this research, such as galactose, arabinose and rhamnose. This may explain the difference between the sugars determined by chromatography (glucose, fructose and sucrose) and sugars determined by titration (total and reducing sugars). This root composition justifies the use of sugary cassava landraces for the production of a concentrate rich in glucose and fructose.

The Manicueira 62 had the highest starch content $\left(4.40 \mathrm{~g}^{100 \mathrm{~g}^{-1}}\right.$ of root, $\left.219 \mathrm{~g} \mathrm{plant}^{-1}\right)$ of the three. However, this content is significantly lower than that of conventional cassava $\left(25-30 \mathrm{~g}^{100 \mathrm{~g}^{-1}}\right.$ of root) (VIEIRA et al., 2008). Based on the estimated root productivity of the Manicueira 62 landrace (57.30ton ha ${ }^{-1}$ ), the yield in starch would be 2.19ton ha $^{-1}$ while that a conventional 12-month-old cassava plant would be more than double (4.5ton $\left.\mathrm{ha}^{-1}\right)$ (SAGRILO et al., 2002).

The Manicueira 62 landrace also had the highest protein $(0.29 \%)$ and lipid $(0.17 \%)$ content,

Table 2 - Root composition of the sugary cassava landraces.

\begin{tabular}{llll}
\hline & & & \\
Component & & Manicueira 62 & Castanhal Iracema \\
\hline Moisture content & $92.97 \pm 0.56^{\mathrm{a}}$ & $90.01 \pm 0.76^{\mathrm{b}}$ & $91.01 \pm 0.98^{\mathrm{b}}$ \\
Reducing sugars & $3.96 \pm 0.06^{\mathrm{b}}$ & $4.67 \pm 0.10^{\mathrm{a}}$ & $3.71 \pm 0.09^{\mathrm{c}}$ \\
Total sugars & $4.76 \pm 0.07^{\mathrm{b}}$ & $5.84 \pm 0.12^{\mathrm{a}}$ & $3.92 \pm 0.04^{\mathrm{c}}$ \\
Glucose & $2.25 \pm 0.29^{\mathrm{a}}$ & $1.31 \pm 0.15^{\mathrm{b}}$ & $1.88 \pm 0.06^{\mathrm{a}}$ \\
Fructose & $1.61 \pm 0.20^{\mathrm{a}}$ & $0.97 \pm 0.11^{\mathrm{b}}$ & $1.54 \pm 0.10^{\mathrm{a}}$ \\
Sucrose & $1.41 \pm 0.16^{\mathrm{a}}$ & $1.17 \pm 0.12^{\mathrm{a}}$ & $0.84 \pm 0.06^{\mathrm{b}}$ \\
Starch & $1.95 \pm 0.03^{\mathrm{b}}$ & $4.40 \pm 0.09^{\mathrm{a}}$ & $1.27 \pm 0.02^{\mathrm{c}}$ \\
Proteins & $0.17 \pm 0.00^{\mathrm{c}}$ & $0.29 \pm 0.01^{\mathrm{a}}$ & $0.20 \pm 0.01^{\mathrm{b}}$ \\
Lipids & $0.06 \pm 0.00^{\mathrm{b}}$ & $0.17 \pm 0.01^{\mathrm{a}}$ & $0.17 \pm 0.01^{\mathrm{a}}$ \\
Ashes & $0.09 \pm 0.03^{\mathrm{a}}$ & $0.16 \pm 0.03^{\mathrm{a}}$ & $0.17 \pm 0.03^{\mathrm{a}}$ \\
Total fibers & ND & ND & $3.01 \pm 0.11$ \\
Insoluble fibers & ND & ND & $2.65 \pm 0.09$ \\
Soluble fibers & ND & ND & 0.36 \\
\hline
\end{tabular}

${ }^{\mathrm{c}} \mathrm{g} 100 \mathrm{~g}^{-1}$ of root (wet basis); ${ }^{\mathrm{d}}$ São Francisco Bag 3 . Mean values in the same row followed by different subscript letters are significantly different ( $\mathrm{P} \leq 0.05$ by Tukey's test); ND - Not determinate. 
not differing statistically $(\mathrm{P}>0.05)$ from the Castanhal Iracema landrace in terms of lipids. On average, the traditional varieties of cassava are made up of $0.53 \%$ protein and $0.17 \%$ lipids. The ash content of the sugary cassava landraces $(\leq 0.17 \%)$ was less than that found in conventional cassava $(0.84 \%)$ (HILLOCKS et al., 2002).

The Castanhal Iracema landrace was made up of $3.01 \%$ of total dietary fiber, most of which was insoluble fiber $(88.03 \%)$. The amount of dietary fiber was determined only for this one landrace since the total sum of the other constituent parts of the other landraces was almost $100 \%$, indicating the low contribution of dietary fiber.

Physicochemical properties of the sugary cassava roots

Table 3 shows the data regarding the physicochemical properties of the sugary cassava landraces. The Castanhal Iracema landrace had lower soluble solids content (4.29\%) and the São Francisco Bag 3 landrace had the lowest $\mathrm{pH}$ (6.62) and the greatest acidity $\left(2.50 \mathrm{meq} \mathrm{NaOH} 100 \mathrm{~g}^{-1}\right.$ of root). As such, all the sugary cassava landraces studied are classified as low acidity products $(\mathrm{pH}>4.6)$, according to FELLOWS (2009). The three sugary cassava landraces had a high $\mathrm{pH}(\geq 6.62)$ and water activity $(\geq 0.98)$ and are thus regarded as being susceptible to degradation when they are not utilized right after harvesting or when they do not undergo appropriate technological processing.

All three sugary cassava landraces were found to have low free cyanide content $\left(<3 \mathrm{mg} \mathrm{kg}^{-1}\right.$ of root) with the Castanhal Iracema landrace having the lowest of the three on average $\left(2.73 \mathrm{mg} \mathrm{kg}^{-1}\right.$ of root). However, the three landraces showed high levels of total cyanide (>100mg kg-1 of root), characterizing them as poisonous or unfit for fresh consumption (BOLHUIS, 1954). VIEIRA et al. (2008) evaluated four sugary cassava landraces and all had cyanide content between 115 and $150 \mathrm{mg} \mathrm{kg}^{-1}$ of root. According to CARDOSO et al. (2005) the proportion of cyanide in the cassava roots can vary from 1 to $1,550 \mathrm{mg} \mathrm{kg}^{-1}$ of root, but the processing of these roots, especially the heating, may reduce their toxicity.

In evaluating the color parameters, the chromaticity coordinate $\mathrm{a}^{*}$ tended towards light green in all roots. According to coordinate $b^{*}$, the three sugary cassava landraces tended towards yellow ( $\left.b^{*}>+6.30\right)$; there was no significant difference (P>0.05) among the samples, thus all the roots had a cream color. The cassava root may have several different colors depending on the variety, with cream-, white-, yellow- or even red-colored roots (CARVALHO et al., 2000).

\section{CONCLUSION}

The three sugary cassava landraces had high proportions of sugars, consisting mainly of glucose and fructose. This root composition justifies the use of sugary cassava landraces for the production of a concentrate rich in glucose and fructose, mainly the São Francisco Bag 3.

The sugary cassava landraces had a high $\mathrm{pH}$ and water activity and are thus regarded as being susceptible to degradation when they are not utilized right after harvesting or when they do not undergo appropriate technological processing.

Table 3 - Physicochemical properties of the sugary cassava roots

\begin{tabular}{|c|c|c|c|}
\hline Properties & S. F. Bag $3^{d}$ & Manicueira 62 & Castanhal Iracema \\
\hline Solid solubles ${ }^{\mathrm{e}}$ & $5.69 \pm 0.12^{\mathrm{a}}$ & $6.29 \pm 0.61^{\mathrm{a}}$ & $4.29 \pm 0.06^{\mathrm{b}}$ \\
\hline Acidity ${ }^{f}$ & $2.50 \pm 0.03^{\mathrm{a}}$ & $1.85 \pm 0.08^{\mathrm{b}}$ & $1.64 \pm 0.07^{c}$ \\
\hline $\mathrm{pH}^{\mathrm{g}}$ & $6.62=0.02^{\mathrm{b}}$ & $6.83=0.05^{\mathrm{a}}$ & $6.83=0.05^{\mathrm{a}}$ \\
\hline Water activity ${ }^{\mathrm{g}}$ & $0.98=0.00^{\mathrm{b}}$ & $0.99=0.00^{\mathrm{a}}$ & $0.99=0.00^{\mathrm{a}}$ \\
\hline Free cyanide ${ }^{\mathrm{h}}$ & $2.92 \pm 0.08^{\mathrm{a}}$ & $2.98=0.07^{\mathrm{a}}$ & $2.73 \pm 0.05^{\mathrm{b}}$ \\
\hline Total cyanide ${ }^{\mathrm{h}}$ & $205.87=4.48^{\mathrm{a}}$ & $198.65 \pm 16.26^{\mathrm{a}}$ & $195.49=3.67^{\mathrm{a}}$ \\
\hline Color parameter, $\mathrm{L}, * \mathrm{~g}$ & $56.39=3.56^{\mathrm{b}}$ & $69.17 \pm 4.40^{\mathrm{a}}$ & $60.69=1.81^{\mathrm{ab}}$ \\
\hline Color parameter, $a^{* g}$ & $-1.18=0.07^{\mathrm{a}}$ & $-0.97=0.07^{\mathrm{b}}$ & $-0.98=0.08^{\mathrm{b}}$ \\
\hline Color parameter, $b$ *g & $+7.32=0.23^{\mathrm{a}}$ & $+6.34 \pm 0.44^{\mathrm{a}}$ & $+7.01 \pm 0.49^{\mathrm{a}}$ \\
\hline
\end{tabular}

${ }^{\mathrm{d}}$ São Francisco Bag 3; ${ }^{\mathrm{e}} \mathrm{B}$ Brix; ${ }^{\mathrm{f}}$ meq. NaOH $100 \mathrm{~g}^{-1}$ of root; ${ }^{\mathrm{g}}$ dimensionless; ${ }^{\mathrm{h}} \mathrm{mg} \mathrm{kg}{ }^{-1}$ of root. Mean values in the same row followed by different subscript letters are significantly different $(\mathrm{P} \leq 0.05$ by Tukey's test).

Ciência Rural, v.43, n.5, mai, 2013. 
All of the sugary cassava landraces showed high levels of total cyanide, characterizing them as poisonous or unfit for fresh consumption.

\section{ACKNOWLEDGMENT}

The authors would like to thank CNPq (Conselho Nacional de Desenvolvimento Científico e Tecnológico) and FAPESPA (Fundação de Amparo à Pesquisa do Estado do Pará) for the financial support, to the Embrapa for the samples and to Dra. Beatriz Rosana Cordenunsi for the Glucose, fructose and sucrose analysis.

\section{REFERENCES}

ALBUQUERQUE, M. A mandioca na Amazônia. Belém: SUDAM, 1969. 222p.

AOAC. Official method of analysis of association of official analytical chemistry. 16.ed. Gaithersburg, 1997. 1200p.

BLIGH, E.G.; DYER, W.J. A rapid method of total lipid extraction and purification. Canadian Journal Biochemistry Physiology, v.37, n.8, p.911-917, 1959. Available from: <http://www. nrcresearchpress.com/toc/cjbp/37/8>. Accessed: Nov. 17, 2011. doi: 10.1139/059-099.

BOLHUIS, G.G. The toxicity of cassava roots. Netherlands Journal of Agricultural Science, v.2, n.3, p.176-185, 1954.

CARDOSO, A.P. et al. Processing of cassava roots to remove cyanogens. Journal of Food Composition and Analysis, v.18, n.5, p.451-460, 2005. Available from: <http://www.sciencedirect. com/science/journal/08891575/18/5>. Accessed: Nov. 17, 2011. doi: 10.1016/j.jfca.2004.04.002.

CARDOSO, E.M. et al. Sugary cassava (Manihot esculenta Crantz): preliminary morphological characterization and agronomic evaluation. In: INTERNATIONAL SCIENTIFIC MEET OF THE CASSAVA BIOTECHNOLOGY NETWORK, 6., 2004 Cali. Expanded abstract. Cali: Centro Internacional de Agricultura Tropical, 2004. Available from: <http://webapp.ciat. cgiar.org/biotechnology/cbn/sixth_international_meeting/PostersPDF/PS-2/E_Cardoso_AAA.pdf>. Accessed: Apr. 9, 2012.

CARVALHO, L.J.C.B. et al. Identification and characterization of a novel cassava (Manihot esculenta Crantz) clone with high free sugar content and novel starch. Plant Molecular Biology, v.56, n.4, p.643-659, 2004. Available at: <http://www.springerlink. com/content/h7769x33x5784x4t/fulltext.pdf >. Accessed: Nov. 17, 2011. doi: 10.1007/s11103-004-4873-9.

CARVALHO, L.J.C.B. et al. Raiz de reserva de mandioca um sistema biológico de múltiplas unidades. Brasília: Embrapa Recursos Genéticos e Biotecnologia, 2000. 16p.

CEREDA, M.P.; VILPOUX, O.F. Tecnologia, uso e potencialidades de tuberosas amiláceas Latino Americanas. São Paulo: Cargill Foundation, 2003. 711p.

CEREDA, M.P. Propriedades gerais do amido. São Paulo: Cargill Foundation, 2001. 221p.
CHROMA METER. Instruction manual. Osaka: Minolta Carnera, 1989. $87 \mathrm{p}$.

DER AGOPIAN, R.G. et al. Identification of fructooligosaccharides in different banana cultivars. Journal of Agricultural and Food Chemistry, v.56, n.9, p.3305-3310, 2008. Available from: <http:// pubs.acs.org/doi/abs/10.1021/jf0730111>. Accessed: Nov. 17, 2011. doi: 10.1021/jf0730111.

ESSERS, A.J.A. Assay for the cyanogen content in cassava products. Wageningen: Wageningen University, 1993. 9p.

FAO (FOOD AND AGRICULTURE ORGANIZATION OF THE UNITED NATIONS). FAOSTAT: top production Cassava. 2009. Accessed: Nov 14, 2011. Online. Available from: <http://faostat. fao.org/site/339/default.aspx>.

FELLOWS, P.J. Food processing technology: principles and practice. 3.ed. Boca Raton: CRC, 2009. 980p.

FUCCILLO, D. et al. Biodiversity in trust. Cambridge UK: Cambridge University, 1997. 371p.

FUKUDA, W.M.G. et al. Caracterização e avaliação de germoplasma de mandioca (Manihot esculenta Crantz). Cruz das Almas: EMBRAPA, 1997. 161p.

HILLOCKS, R.J. et al. Cassava: biology, production and utilization. New York: CABI, 2002. 332p.

RICKARD, J.E.; BEHN, K.R. Evaluation of acid and enzyme hydrolytic methods for the determination of cassava starch. Journal of the Science of Food and Agriculture, v.41, n.4, p.373-379, 1987. Available from: <http://onlinelibrary.wiley.com/ doi/10.1002/jsfa.2740410409/ abstract>. Accessed: Nov. 17, 2011. doi: $10.1002 /$ jsfa.2740410409.

SAGRILO, E. et al. Effect of the harvesting time in the vegetative growth, yield and quality of the storage roots of three cassava cultivars. Bragantia, v.61, n.2, p.115-125, 2002. Available from: <http://www.scielo.br/scielo.php?pid=S0006$87052002000200005 \&$ script $=$ sci_abstract $>$. Accessed: Nov. 17, 2011. doi: $10.1590 /$ S0006-87052002000200005.

SIQUEIRA, M.V.B.M. et al. Microsatellite polymorphisms in cassava landraces from the Cerrado biome, Mato Grosso do Sul, Brazil. Biochemical Genetics, v.48, n.9-10, p.879-895, 2010. Available at: <http://www.springerlink.com/content/ m0r7266082x35k87/>. Accessed: Nov. 17, 2011. doi: 10.1007/ s10528-010-9369-5.

TAYLOR, N. et al. Development and application of transgenic technologies in cassava. Plant Molecular Biology, v.56, n.4, p.671-688, 2004. Available at: <http://www.springerlink.com/ content/j4001qhu4276w370/>. Accessed: Nov. 17, 2011. doi: $10.1007 / \mathrm{s} 11103-004-4872-\mathrm{x}$.

VIEIRA, E.A. et al. Genetic divergence among sugary and nonsugary cassava accessions. Pesquisa Agropecuária Brasileira, v.43, n.12, p.1707-1715, 2008. Available at: <http:// www.scielo.br/scielo.php?script=sci_arttext\&pid=S0100-204X20 $08001200010 \& \operatorname{lng}=\mathrm{en} \& \mathrm{nrm}=\mathrm{iso} \& \mathrm{t} \operatorname{lng}=\mathrm{pt}>$. Accessed: Nov. 17, 2011. doi: 10.1590/S0100-204X2008001200010. 